\title{
Erratum to: Hydrothermal decomposition of various crystalline celluloses as treated by semi-flow hot-compressed water
}

\author{
Rosnah Abdullah • Kazuyoshi Ueda • \\ Shiro Saka
}

Published online: 8 August 2014

(c) The Japan Wood Research Society 2014

\section{Erratum to: J Wood Sci}

\section{DOI 10.1007/s10086-014-1401-7}

After publication of the paper, some errors in calculation were found in Table 2. The changes do not affect the conclusions of the paper.

In the original paper published, the following changes should be made,

1. In the 4th paragraph of "Decomposition kinetics", the sentence "The $E_{\mathrm{a}}$ for group I and group II celluloses are, respectively, $>70 \mathrm{~kJ} / \mathrm{mol}$ and in between 50 and $60 \mathrm{~kJ} / \mathrm{mol}$ ' should be replaced by 'The $E_{\mathrm{a}}$ for group I and group II celluloses are, respectively, $>130$ and $100 \mathrm{~kJ} / \mathrm{mol}^{\prime}$.

2. The corrected Table 2 is shown here.
The online version of the original article can be found under doi:10.1007/s10086-014-1401-7.

\section{R. Abdullah · S. Saka $(\bowtie)$}

Department of Socio-Environmental Energy Science, Graduate

School of Energy Science, Kyoto University, Yoshida-

Honmachi, Sakyo-ku, Kyoto 606-8501, Japan

e-mail: saka@energy.kyoto-u.ac.jp

K. Ueda

Department of Advanced Materials Chemistry, Graduate School of Engineering, Yokohama National University,

Yokohama 240-8501, Japan
Table 2 The apparent activation energies of various types of crystalline celluloses as treated by semi-flow $\mathrm{HCW}$ at $230-270{ }^{\circ} \mathrm{C} /$ $10 \mathrm{MPa} / 15 \mathrm{~min}$

Cellulose Activation energy, $E_{\mathrm{a}}(\mathrm{kJ} / \mathrm{mol})$

Group I

Cell I

Cell III

149

Cell IV

172

Group II

Cell II

102

Cell III II

112

Cell IV II 